\title{
An Updated Review of Phytochemical Compounds and Pharmacology Activities of Artocarpus genus
}

\author{
Anastasia Karina Buddhisuharto ${ }^{1, *(\mathbb{D})}$, Hegar Pramastya ${ }^{2(\mathbb{D})}$, Muhamad Insanu ${ }^{3(\mathbb{D})}$, Irda Fidrianny 4 (D) \\ 1 Department of Pharmaceutical Biology, School of Pharmacy, Bandung Institute of Technology, Bandung, Indonesia; \\ akarinabuddhisuharto@gmail.com (A.K.B.); hegarpramastya@fa.itb.ac.id (H.P.); muhamad.insanu@gmail.com (M.I.); \\ irdafidrianny@gmail.com (I.F.); \\ * Correspondence: akarinabuddhisuharto@gmail.com;
}

Scopus Author ID 54790959000

Received: 22.02.2021; Revised: 19.03.2021; Accepted: 22.03.2021; Published: 2.04.2021

\begin{abstract}
The Artocarpus genus from the Moraceae family, widely planted in tropic and subtropic regions of Asia, can be used as a food commodity and treat diseases. In this study, the phytochemical compounds and pharmacological activities of several Artocarpus species were examined. The literature review was performed to elaborate phytochemical compounds and pharmacological activities of Artocarpus plants. The reference articles have DOI and were obtained through the Scopus and PubMed websites database to ensure their validity and reliable contents. This literature study was made by using minimum 50 articles from the last 10 years. Based on this study, it was known that some Artocarpus species contained an abundance of flavonoids, phenols, steroids, tannins, saponins, and triterpenoids. The compounds have various activities such as antimicrobial, antifungal, antiviral, antidiabetic, anticancer, antimalarial, anti-inflammatory, and antioxidant. It needed more further studies about Artocarpus to comprehend the flavonoid and triterpenoid mechanism as an antimalarial agent.
\end{abstract}

Keywords: Artocarpus; phytochemical compounds; pharmacological activities.

(C) 2021 by the authors. This article is an open-access article distributed under the terms and conditions of the Creative Commons Attribution (CC BY) license (https://creativecommons.org/licenses/by/4.0/).

\section{Introduction}

Moraceae family is well known as mulberry family and represents 37 genus and around 1050 species [1]. Artocarpus genus, a genus belonging to the Moraceae family, comprehends 50 species found in tropic and subtropic Asia regions [2]. According to some studies, the Moraceae family is designated as monophyletic and heterogeneous [3].

The name of Artocarpus came from the Greek words 'artos' and 'karpos', which have meanings of bread and fruit; therefore, the fruits are generally named as breadfruit [4]. Breadfruit is rich in carbohydrates and minerals, making them a staple food and overcoming malnutrition [5]. Besides, breadfruit has bioactive compounds that provide therapeutic properties [6].

Various Artocarpus species like Artocarpus heterophyllus, Artocarpus altilis, Artocarpus hirsutus, Artocarpus lakoocha, and Artocarpus camansi were useful for treating disease [7]. The indicated species were researched for their phytochemical compounds and pharmacological activities. 


\section{Materials and Methods}

Data in this article were obtained from international scientific journals in Scopus, PubMed, Science Direct, and Elsevier portal using meta-analysis-based PRISMA (Preferred Reporting Items for Systematic Review and Meta-Analysis), published in the last 10 years, including 20 articles in the last 2 years.

\section{Results and Discussion}

\subsection{Phytochemical compounds of Artocarpus genus.}

The Artocarpus plants are proclaimed to be rich in phenolic compounds such as flavonoids, stilbenoids, and arylbenzofurons [8]. Further studies on Artocarpus species are done to observe more phytochemical compounds from correlated plants.

Based on previous studies, Artocarpus heterophyllus comprised phenolic compounds, flavonoids, arylbenzofurans, and stilbenoids [9]. Artocarpus altilis consisted of steroids, anthraquinone, glycoside, tannins, and flavonoids [10]. Artocarpus hirsutus contained sterols, terpenoids, tannins, saponins, flavonoids, and lactones [11]. Research on Artocarpus lakoocha showed the presence of flavonoids and tannins [12]. Artocarpus camansi represented polyprenol, squalene, and $\beta$-sitosterol [13].

The summary of some secondary metabolites produced by Artocarpus species was shown in Table 1.

Table 1. Phytochemical compounds.

\begin{tabular}{|c|c|c|c|c|}
\hline $\begin{array}{l}\text { Artocarpus } \\
\text { species }\end{array}$ & Plant part & Compounds & $\begin{array}{l}\text { Extraction } \\
\text { Solvent }\end{array}$ & Ref \\
\hline \multirow{8}{*}{$\begin{array}{l}\text { Artocarpus } \\
\text { heterophyllus } \\
\text { Lam. }\end{array}$} & Flowers & Carotenoids, flavonoids & Ethanol, methanol & {$[14]$} \\
\hline & Leaves & Chromones, flavonoids, catechin, chlorogenic acid, & Ethanol, methanol & {$[15,16]$} \\
\hline & Roots & $\begin{array}{l}\text { Flavonoids (free 6- or 8-prenylated substituted } \\
\text { flavones, free 8-geranyl substituted flavones, free 3- } \\
\text { prenylated substituted flavones) }\end{array}$ & Ethanol & {$[17]$} \\
\hline & Stems & Chromones, flavonoids & Methanol & {$[15]$} \\
\hline & Bark & \multirow{3}{*}{$\begin{array}{l}\text { Flavonoids, phenols, saponins, (epi)catechin, } \\
\text { glycosides }\end{array}$} & \multirow[t]{3}{*}{ Ethanol, methanol } & \multirow[t]{3}{*}[17-20]{} \\
\hline & Peels & & & \\
\hline & Pulps & & & \\
\hline & Seeds & $\begin{array}{l}\text { Flavonoids, tannins, steroids, glycosides, saponins, } \\
\text { anthraquinones, phenols }\end{array}$ & $\begin{array}{l}\text { Ethanol, } \\
\text { n-hexane, } \\
\text { methanol }\end{array}$ & $\begin{array}{c}{[18,21,} \\
22]\end{array}$ \\
\hline \multirow{8}{*}{$\begin{array}{l}\text { Artocarpus } \\
\text { altilis }\end{array}$} & Peels & Alkaloids, flavonoids, phenols, tannins, glycosides & Methanol & [23] \\
\hline & Bark & Prenylated stilbenoids & Ethanol & [24] \\
\hline & Heartwood & \multirow{2}{*}{$\begin{array}{l}\text { Artocarpin, norartocarpetin, cycloartocarpin, artonol } \\
\mathrm{B} \text {, cyclomorusin, artoflavone A, cyclogeracommunin, } \\
\text { and artonin } \mathrm{M} \text {, prenylated stilbenoids, flavonoids, } \\
\text { isocycloartobiloxanthon, furanocyclocommunin }\end{array}$} & \multirow[t]{2}{*}{ Ethanol, methanol } & \multirow[t]{2}{*}[24,25]{} \\
\hline & Cortex & & & \\
\hline & Fruits & Flavonols, tannins, catechins, monoterpenes & Methanol & [26] \\
\hline & Leaves & $\begin{array}{l}\text { Phenols, flavonoids, prenylated aurone, cycloaltilisin } \\
\text { 7, artocarpaurone, prenylated chalcones, prenylated } \\
\text { flavanones, triterpens, hexadecanoic acid, cis-13- } \\
\text { octadecenoic acid, and cinnamic acid }\end{array}$ & Ethanol, methanol & $\begin{array}{c}{[25,27,} \\
28]\end{array}$ \\
\hline & Root & \multirow[t]{2}{*}{ Prenylflavonoids, triterpenoids } & \multirow[t]{2}{*}{ Ethanol } & \multirow[t]{2}{*}{ [29] } \\
\hline & Seeds & & & \\
\hline \multirow{3}{*}{$\begin{array}{l}\text { Artocarpus } \\
\text { hirsutus Lam. }\end{array}$} & Stem & Sterols, triterpenoids, flavonoids, tannins, saponins & Ethanol & [30] \\
\hline & Leaves & $\begin{array}{l}\text { Glycosides, alkaloids, sterols, triterpenoids, } \\
\text { flavonoids, tannins, saponins }\end{array}$ & $\begin{array}{l}\text { Acetone, ethanol, } \\
\text { methanol }\end{array}$ & [30-32] \\
\hline & Fruits & $\begin{array}{llll}\begin{array}{l}\text { Alkaloids, flavonoids, } \\
\text { terpenoids }\end{array} & \text { glycosides, saponins, } \\
\end{array}$ & $\begin{array}{l}\text { Acetone, } \\
\text { methanol }\end{array}$ & [32] \\
\hline \multirow{3}{*}{$\begin{array}{l}\text { Artocarpus } \\
\text { lakoocha Roxb. }\end{array}$} & Flowers & Carotenoids, flavonoids & Ethanol, methanol & {$[14]$} \\
\hline & Bark & \multirow{2}{*}{$\begin{array}{l}\text { Flavonoid (lakoochanone), lakoochanosides, catechin, } \\
\text { moracin C, integrin, cyclocommunin, engeletin, }\end{array}$} & \multirow[t]{2}{*}{ Acetone } & \multirow[t]{2}{*}[33,34]{} \\
\hline & Twigs & & & \\
\hline
\end{tabular}




\begin{tabular}{|c|c|c|c|c|}
\hline $\begin{array}{l}\text { Artocarpus } \\
\text { species }\end{array}$ & Plant part & Compounds & $\begin{array}{l}\text { Extraction } \\
\text { Solvent }\end{array}$ & Ref \\
\hline & & $\begin{array}{l}\text { isogemichalcone } \mathrm{B} \text {, morachalcone } \mathrm{A} \text {, heterophyllene } \\
\mathrm{B} \text {, albanin } \mathrm{A} \text {, moracin } \mathrm{M} \text {, artocarpesin, norartocarpin, } \\
\text { resveratrol, artocarpanone, oxyresveratrol }\end{array}$ & & \\
\hline & Heartwood & Oxyresveratrol & Ethanol & {$[35,36]$} \\
\hline & Leaves & $\begin{array}{l}\text { Flavonoids, phenols, tannins, eicosane, diethyl } \\
\text { phthalate, 9-octyl eicosane }\end{array}$ & $\begin{array}{l}\text { Pentane, } \\
\text { n-hexane, ethyl } \\
\text { acetate, acetone, } \\
\text { methanol }\end{array}$ & [37] \\
\hline & Fruits & $\begin{array}{l}\text { Flavonoids, tannins, terpenoids, saponins, glycosides, } \\
\text { alkaloids, steroids, quercetin, kaempferol }\end{array}$ & Methanol & [38] \\
\hline \multirow{3}{*}{$\begin{array}{l}\text { Artocarpus } \\
\text { camansi }\end{array}$} & Leaves & \multirow{2}{*}{$\begin{array}{l}\text { Friedelinol, squalene, } \beta \text {-sitosterol, stigmasterol, } \\
\text { phytol, polyprenol, cycloartenol }\end{array}$} & \multirow[t]{2}{*}{ Acetone } & \multirow[t]{2}{*}{ [13] } \\
\hline & Stem & & & \\
\hline & Peels & Steroids, triterpenoids & n-Hexane & [39] \\
\hline
\end{tabular}

Based on Table 1, phytochemical compounds that were found in abundance among the five species of Artocarpus were flavonoids, glycosides, tannins, phenols, saponins, alkaloids, steroids, and triterpenoids. Flavonoids can be found in almost every part of A. heterophyllus, A. altilis, A. hirsutus, dan A. lakoocha, especially in leaves and fruits. Glycosides were presented in fruits of A. heterophyllus, A. altilis, A. hirsutus, dan A. lakoocha. Tannins are obtained from A. heterophyllus's seeds, A. altilis' and A. lakoocha's fruits, as well in $A$. hirsutus' and A. lakoocha's leaves. Phenols were found in stem of A. heterophyllus and $A$. altilis, also in leaves of A. lakoocha. Saponins were plenty in A. heterophyllus', A. hirsutus', and A. lakoocha's fruits. Alkaloids can be found in A. altilis', A. hirsutus', and A. lakoocha's fruits. Steroids can be found in A. heterophyllus' seeds, A. lakoocha's fruit, and A. camansi's peels. Meanwhile, triterpenoids were obtained from A. altilis's roots and seeds, A. hirsutus' stem, leaves, and A. camansi's peels. The structure of certain compounds isolated from Artocarpus plants is as shown in Fig. 1.
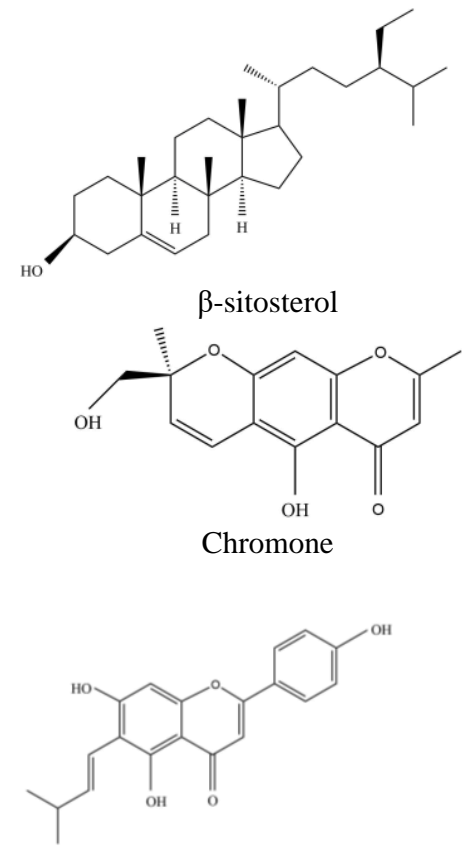

Flavonoid

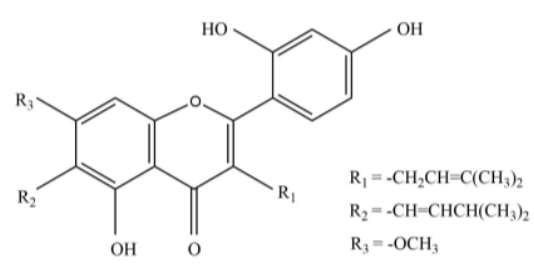

Artocarpin

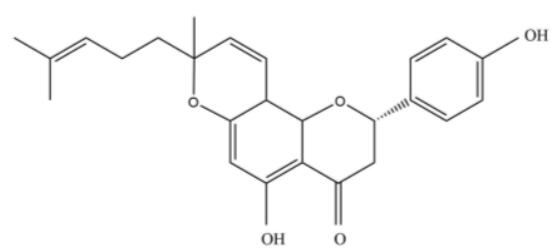

Cycloaltilisin 7

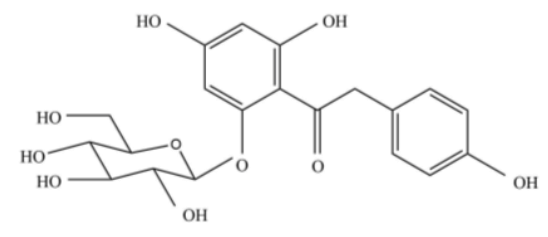

Lakoochanoside

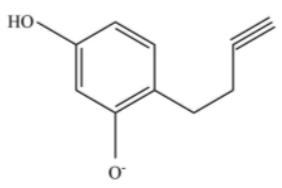

(Epi)catechin

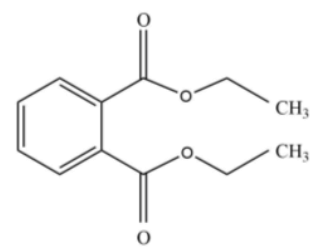

Diethyl phthalate

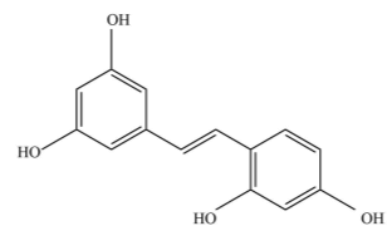

Oxyresveratrol

Figure 1. Chemical structure of compounds isolated from Artocarpus

\subsection{Pharmacological activities of Artocarpus genus.}

The Artocarpus plants were reported to have the following pharmacological properties, namely as anti-inflammatory, antioxidant, antimalarial, antifungal activities, cytotoxic, 
together with tyrosinase inhibitory activities [40]. The pharmacological activities of previous Artocarpus plants were evinced in the explanation below:

\subsubsection{Antimicrobial activity.}

A. heterophyllus seeds extracts against methicillin-resistant $S$. aureus, and multidrugresistant $P$. aeruginosa were tested using the agar well diffusion method. This study showed the MIC values of methicillin-resistant $S$. aureus were $62.25 \mathrm{mg} / \mathrm{ml}$ (in ethanol) and $125 \mathrm{mg} / \mathrm{ml}$ (in hexane), meanwhile, MIC values of multidrug-resistant $P$. aeruginosa were $125 \mathrm{mg} / \mathrm{ml}$ (in ethanol and hexane) [21]. A study revealed that flavonoids play the role of inhibiting bacterial movement and reduce its biofilm formation in P. aeruginosa and inhibit bacterial toxins production of $S$. aureus [41].

Consequently, hexadecanoic acid, cis-13-octadecenoic acid, and cinnamic acid from $A$. altilis leave extracts had antimicrobial activity. The study reported the inhibition against $\mathrm{B}$. cereus and $E$. coli's growth; respectively, the diameters zone of inhibition was $0.766 \pm 0.06 \mathrm{~cm}$ and $1.27 \pm 0.12 \mathrm{~cm}[28]$.

\subsubsection{Antidiabetic activity.}

In a recent study, 2-3 months rats were induced with streptozotocin to obtain rats with hyperglycemia; the blood glucose level was measured 14 days after the treatment. At the 400 $\mathrm{mg} / \mathrm{kg}$ dose, ethanolic extract of $A$. heterophyllus seeds was injected into the diabetic rats. The result showed that the extract had an antidiabetic activity by reducing blood glucose levels by $61.73 \%$ [22]. The existence of saponins can lower cholesterol and blood glucose levels [20].

\subsubsection{Anti-inflammatory activity.}

Chromones and flavonoids compounds extracted with methanol from leaves and stems of A. heterophyllus had anti-inflammatory activity. Each compound's structure exposed its inhibitory potential against the production of nitric oxide (NO) in mouse macrophage RAW 264.7 cells. The experiment showed $\mathrm{IC}_{50}$ values range from $0.48 \pm 0.05$ to $19.87 \pm 0.21 \mu \mathrm{M}$ [15].

On the other hand, $200 \mathrm{mg} / \mathrm{kg}$ dose of A. altilis leaves extracts had an ability to reduce inflammation in chronic inflammatory rats that were induced by complete adjuvant Freund (CFA) [42]. Meanwhile, in another research, the IC50 values of $A$. laoocha heartwood extract were $31.43 \mu \mathrm{g} / \mathrm{ml}$ [35]. Oxyresveratrol that was obtained from the extract was capable of suppressing TNF- $\alpha$ and NF- $\mathrm{KB}$ expression levels, which work as proinflammatory mediators [36].

\subsubsection{Antioxidant activity.}

Peel, pulp and seed extracts of A. heterophyllus expressed DPPH scavenging activities due to the existing phenolic and flavonoid compounds. Using methanol as extracting solvent, the value of IC50 DPPH for A. heterophyllus peel, pulp, and seed extracts was $0.02 \mathrm{mg} / \mathrm{ml}$, $0.23 \mathrm{mg} / \mathrm{ml}$, and $7.62 \mathrm{mg} / \mathrm{ml}$, respectively [18]. The hydroxyl groups linked to the aromatic ring in flavonoid structure allowed them to scavenge free radicals through redox reaction [43].

Furthermore, A. altilis stem bark extract had high flavonoids contents as well. The percentage inhibition of DPPH free radical by A. altilis stem bark extract was $62.5 \%$ at 100 
$\mu \mathrm{g} / \mathrm{ml}$ [44]. In another study, the radical scavenging activity of $A$. hirsutus seeds extracts was $51.6 \pm 1.52 \%$ [45]. The seed oils contained phenolic compounds, which performed antioxidant activity. Phenolic compounds act as an antioxidant group by donating hydrogen to free radicals [46].

\subsubsection{Anticancer activity.}

The presence of chromones and flavonoids in the methanolic extract from leaves and stems of A. heterophyllus showed antiproliferative activity. Those compounds presented significant inhibitory effects against various human cancer cells with an $\mathrm{IC}_{50}$ range from 0.36 \pm 0.02 to $22.09 \pm 0.16 \mu \mathrm{M}[15]$.

The presence of quercetin in methanol extract of $A$. altilis pulp was able to induce cell apoptosis in HeLa cell with $\mathrm{IC}_{50}$ values determined to be $50 \mu \mathrm{g} / \mathrm{ml}$ [47]. In another study, leaves extract of A. camansi demonstrated high cytotoxic activity against breast carcinoma cells (MCF-7) with IC50 value $9.58 \pm 3.29 \mu \mathrm{g} / \mathrm{ml}[48]$.

\subsubsection{Antifungal activity.}

Catechin and chlorogenic acid compounds from leaves extract of A. heterophyllus showed high inhibition percentage $(83.78 \pm 1.25 \%)$ against $C$. gloeosporioides [16]. Catechin exhibited antifungal activity by inhibiting cAMP synthesis and interrupting intracellular signaling pathways in fungal, known as the MAP kinase cascade [49]. In a different study, the minimum inhibitory concentration (MIC) of A. altilis leaves extracts in methanol against Candida albicans was $475 \mathrm{mg} / \mathrm{ml}[50]$.

\subsubsection{Antiviral activity.}

In a present study, A. heterophyllus, A. altilis, A. camansi leaves extracts were tested on hepatitis $\mathrm{C}$ virus (HCV) infected cells to observe their antiviral activity. The $\mathrm{IC}_{50}$ value for A. heterophyllus ethanolic extract, A. altilis methanolic extract, and A. camansi methanolic extract, were $12.9 \pm 2.6 \mu \mathrm{g} / \mathrm{ml}, 10.7 \pm 1.6 \mu \mathrm{g} / \mathrm{ml}$, and $13.0 \pm 0.7 \mu \mathrm{g} / \mathrm{ml}$, respectively [51]. Flavonoids obtained from Artocarpus species effectively in blocking viral transcription and translation, inhibit viral replication, and prevent virus attachment into cells [52].

\subsubsection{Antimalarial activity.}

In new research, ethanolic extract of $A$. altilis leaves can inhibit the growth of $P$. falciparum, proven from the IC50 value, which was $1.32 \mu \mathrm{g} / \mathrm{ml}$ at the dose of $0.82 \mathrm{mg} / \mathrm{kg}$ [53]. Prenylflavonoids and triterpenoids that were gained from A. altilis extract work as antimalarial constituents [29].

\section{Conclusions}

Recent research over the last 10 years on the Artocarpus genus has provided diverse information to determine their phytochemical compounds and pharmacological activities. The relating bioactive compounds can potentially treat infection caused by microorganisms and diseases like diabetes, cancer, and malaria. However, further studies for some Artocarpus plants must discover unrevealed bioactive compounds and enrich their pharmacological 
activities data. Specifically, research about Artocarpus to comprehend the flavonoid and triterpenoid mechanism as an antimalarial agent.

\section{Funding}

This research received no external funding.

\section{Acknowledgments}

The authors wish to respect the facilities support of the Department of Pharmaceutical Biology, School of Pharmacy, Bandung Institute of Technology, Indonesia.

\section{Conflicts of Interest}

The authors declare no conflict of interest.

\section{References}

1. Sa, I.S.; Neves, K.O.; Guimaraes, A.C.; Silva, F M.; Nunomura, R.C. Chalcones and flavans from the bark of Brosimum acutifolium subsp. interjectum (Moraceae). Biochem Syst Ecol 2020, 93, https://doi.org/10.1016/j.bse.2020.104175.

2. Xu, L.; Liu, X.; Lin, Q.; Wang, Y.; He, X.; Zhou, Z. Prenylflavanones and lignans from the twigs of Artocarpus pithecogallus. Magn Reson Chem 2019, 57, 506-511, https://doi.org/10.1002/mrc.4875.

3. Zerega, N.J.; Supardi, M.N.; Motley, T.J. Phylogeny and Recircumscription of Artocarpeae (Moraceae) with a Focus on Artocarpus. Syst Bot 2010, 35, 766-782.

4. Sikarwar, M.S.; Hui, B.J.; Subramaniam, K.; Valeisamy, B.D.; Yean, L.K.; Balaji, K. A Review on Artocarpus altilis (Parkinson) Fosberg (breadfruit). J Appl Pharm Sci 2014, 4, 91-97.

5. Appiah, F.; Oduro, I.; Ellis, W.O. Proximate and Mineral Composition of Artocarpus altilis Pulp Flour as Affected by Fermentation. Pakistan J Nutr 2011, 10, 653-657, https://doi.org/10.3923/pjn.2011.653.657.

6. Goncalves, N.G.; Araujo, J.I.; Magalhaes, F.E.; Mendes, F.R.; Lobo, M.D.; Moreira, A.C.; Moreira, R.A. Protein fraction from Artocarpus altilis pulp exhibits antioxidant properties and reverses anxiety behavior in adult zebrafish via the serotoninergic system. $J$ Funct Foods 2020, 66, https://doi.org/10.1016/j.jff.2019.103772.

7. Nayak, M.; Nagarajan, A.; Majeed, M. Pharmacognostic Evaluation of Leaf and Stem Wood Extracts of Artocarpus hirsutus Lam. Pharmacogn J 2017, 9, 887-894, https://doi.org/10.5530/pj.2017.6.139.

8. Yen, K.H.; Nyokat, N.; Kutoi, C.J.; Hamzah, A.S.; Lim, I.F. Chemical constituents of Artocarpus odoratissimus from Sarawak. J Appl Pharm Sci 2017, 7, 137-141,https://doi.org/10.7324/JAPS.2017.70819.

9. Burci, L.M.; Silva, C.B.; Rondon, J.N.; Silva, L.M.; Andrade, S.F.; Miguel, O.G.; Dias, J.F.; Miguel, D.M. Acute and subacute (28 days) toxicity, hemolytic and cytotoxic effect of Artocarpus heterophyllus seed extracts. Toxicol Rep 2019, 6, 1304-1308, https://doi.org/10.1016/j.toxrep.2018.02.006.

10. Sikarwar, M.S.; Hui, B.; Subramaniam, K.; Valeisamy, B.D.; Yean, L.K.; Balaji, K. Pharmacognostical, phytochemical and total phenolic content of Artocarpus altilis (Parkinson) fosberg leaves. J Appl Pharm Sci 2015, 5, 94-100, https://doi.org/10.7324/JAPS.2015.50518.

11. Nayak, M.; Nagarajan, A.; Majeed, M. Pharmacognostic evaluation of leaf and stem wood extracts of Artocarpus hirsutus Lam. Pharmacogn J 2017, 9, 887-894, https://doi.org/10.5530/pj.2017.6.139.

12. Bhattacharya, E.; Dutta, R.; Chakraborty, S.; Biswas, S.M. Phytochemical profiling of Artocarpus lakoocha Roxb. leaf methanol extract and its antioxidant, antimicrobial and antioxidative activities. Asian Pac J Trop Biomed 2019, 9, 484-492, https://doi.org/10.4103/2221-1691.270984.

13. Tsai, P.W.; Cruz, K.A.; Shen, C.C.; Chiou, C.T.; Ragasa, C.Y. Chemical constituents of Artocarpus camansi. Pharmacogn J 2013, 5, 80-82, https://doi.org/10.1016/j.phcgj.2012.06.001.

14. Gupta, A.K.; Rather, M.A.; Jha, A.K.; Shashank, A.; Singhal, S.; Sharma, M.; Pathak, U.; Sharma, D.; Mastinu, A. Artocarpus lakoocha Roxb. and Artocarpus heterophyllus Lam. Flowers: New Sources of Bioactive Compounds. Plants 2020, 9, https://doi.org/10.3390/plants9101329.

15. Liu, Y.P.; Yu, X.M.; Zhang, W.; Wang, T.; Jiang, B.; Tang, H.X.; Su, Q.T.; Fu, Y.H. Prenylated chromones and flavonoids from Artocarpus heterophyllus with their potential antiproliferative and anti-inflammatory activities. J Heterocycl Chem. 2020, 101, https://doi.org/10.1016/j.bioorg.2020.104030.

16. Gonzalez, Y.V.; Sanchez, J.A.; Santoyo, M.C. Characterization and antifungal activity of jackfruit (Artocarpus heterophyllus Lam.) leaf extract obtained using conventional and emerging technologies. Food Chem 2020, 330, https://doi.org/10.1016/j.foodchem.2020.127211. 
17. Ye, J.B.; Ren, G.; Li, W.Y.; Zhong, G.Y.; Zhang, M.; Yuan, J.B.; Lu, T. Characterization and identification of prenylated flavonoids from Artocarpus heterophyllus Lam. roots by quadrupole time-of-flight and linear trap quadrupole orbitrap mass spectrometry. Molecules 24, https://doi.org/10.3390/molecules24244591.

18. Zhang, L.; Tu, Z.; Xie, X.; Wang, H.; Wang, Z.; Sha, X.; Lua, Y. Jackfruit (Artocarpus heterophyllus Lam.) peel: a better source of antioxidants and a-glucosidase inhibitors than pulp, flake and seed, and phytochemical profile by HPLC-QTOF-MS/MS. Food Chem 2017, 234, 303-313, https://doi.org/10.1016/j.foodchem.2017.05.003.

19. Ilmi, H.M.; Elya, B.; Handayani, R. Association between total phenol and flavonoid contents in Artocarpus heterophyllus (jackfruit) bark and leaf extracts and lipoxygenase inhibition. Int J App Pharm 2020, 12, 252256, https://doi.org/10.22159/ijap.2020.v12s1.FF055.

20. Ajiboye, B.O.; Ojo, O.A.; Adeyonu, O.; Imiere, O.; Oyinloye, B.E.; Ogunmodede, O. Ameliorative activity of ethanolic extract of Artocarpus heterophyllus stem bark on alloxan-induced diabetic rats. Adv Pharm Bull 2018, 8, 141-147.

21. Eve, A.; Aliero, A.A.; Nalubiri, D.; Adeyemo, R.O.; Akinola, S.A.; Pius, T.; Nabaasa, S.; Nabukeera, S.; Alkali, B.; Ntulume, I. In vitro antibacterial activity of crude extracts of Artocarpus heterophyllus seeds against selected diarrhoea-causing superbug bacteria. Sci World J 2020, 2020, https://doi.org/10.1155/2020/9813970.

22. Dwitiyanti, D.; Rachmania, R.A.; Efendi, K.; Septiani, R.; Jihadudin, P. In vivo activities and in silico study of jackfruit seeds (Artocarpus heterophyllus Lam.) on the reduction of blood sugar levels of gestational diabetes rate induced by streptozotocin. Maced J Med Sci 2019, 7, 3819-3826.

23. Marjoni, M.R.; Sidik, F.; Ovisa, F.; Sukma, Y. Extraction of antioxidants from fruit peel of Artocarpus altilis. Int J Green Pharm 2018, 12, 284-289, https://doi.org/10.22377/ijgp.v12i01.1635.

24. Hosek, J.; Lelakova, V.; Bobal, P.; Pizova, H.; Gazdova, M.; Malanik, M.; Jakubczyk, K.; Vesely, O.; Landa, P.; Temml, V.; Schuster, D.; Prachyawarakorn, V.; Pailee, P.; Ren, G.; Zpurny, F.; Oravec, M.; Smejkal, K. Prenylated stilbenoids affect inflammation by inhibiting the NF-kB/AP-1 signaling pathway and cyclooxygenases and lipoxygenase. $J$ Nat Prod 2019, 82, 1839-1848, https://doi.org/10.1021/acs.jnatprod.9b00081.

25. Lan, W.C.; Tzeng, C.W.; Lin, C.C.; Yen, F.L.; Ko, H.H. Prenylated flavonoids from Artocarpus altilis: antioxidant activities and inhibitory effects on melanin production. Phytochemistry 2013, 89, 78-88, https://doi.org/10.1016/j.phytochem.2013.01.011.

26. Soifoini, T.; Donno, D.; Jeannoda, V.; Rakotoniaina, E.; Hamidou, S.; Achmet, S.M.; Solo, N.R.; Afraitane, K.; Giacoma, C.; Beccaro, G.L. Bioactive compounds, nutritional traits, and antioxidant properties of Artocarpus altilis (Parkinson) fruits: exploiting a potential functional food for food security on the Comoros Islands. J Food Qual 2018, 2018, https://doi.org/10.1155/2018/5697928.

27. Huong, T.T.; Cuong, N.X.; Tram, L.H.; Quang, T.T.; Duong, L.V.; Nam, N.H.; Dat, N.T.; Huong, P.T.; Diep, C.N.; Kiem, P.V.; Minh, C.V. A new prenylated aurone from Artocarpus altilis. J Asian Nat Prod Res 2012, 14, 923-928, https://doi.org/10.1080/10286020.2012.702758.

28. Ahmad, M.N.; Karim, N.U.; Normaya, E.; Piah, B.M.; Iqbal, A.; Bulat, K.H. Artocarpus altilis extracts as a food-borne pathogen and oxidation inhibitors: RSM, COSMO RS, and molecular docking approaches. Sci Rep 2020, 10, https://doi.org/10.1038/s41598-020-66488-7.

29. Adebajo, A.C.; Odediran, S.A.; Aliyu, F.A.; Nwafor, P.A.; Nwoko, N.T.; Umana, U.S. In vivo antiplasmodial potentials of the combinations of four Nigerian antimalarial plants. Molecules 2014, 19, 13136-13146, https://doi.org/10.3390/molecules190913136.

30. Mahadeva, N.; Ananthanarayanan, N.; Muhammed, M. Pharmacognostic evaluation of leaf and stem wood extracts of Artocarpus hirsutus Lam. Pharmacogn J 2017, 9, 887-894, https://doi.org/10.5530/pj.2017.9.139.

31. Patel, J.; Reddy, V.; Kumar, S. Preliminary phytochemical screening and hepatoprotective activity of methanol extract of Artocarpus hirsutus leaves. Int $J$ Phytomedicine 2016, 8 , https://doi.org/10.5138/09750185.1900.

32. Shanmugapriya, K.; Akanya, S.; Anderson, C.B.; Berril, N.S.; Prakash, P.R.; Suganya, V. Phytochemical screening of Artocarpus hirsutus and its antimicrobial potential. Asian J Pharm Clin Res 2017, 10, 298302, https://doi.org/10.22159/ajpcr.2017.v10i6.17669.

33. Boonyaketgoson, S.; Du, Y.; Murillo, A.L.; Cassera, M.B.; Kingston, D.G.; Trisuwan, K. Flavanones from the twigs and barks of Artocarpus lakoocha having antiplasmodial and anti-TB activities. J-STAGE 2020, 68, 671-674, https://doi.org/10.1248/cpb.c20-00080.

34. Boonyaketgoson, S.; Rukachaisirikul, V.; Phongpaichit; Trisuwan, K. Deoxybenzoin and flavan derivatives from the twigs of Artocarpus lakoocha. Phytochem Lett 2019, 31, 96-100, https://doi.org/10.1016/j.phytol.2019.03.020.

35. Hankitticha, P.; Buacheen, P.; Pitchakarn, P.; Takuathung, M.N.; Wikan, N.; Smith, D.R.; Potikanond, S.; Nimlamool, W. Artocarpus lakoocha extract inhibits LPS-induced inflammatory response in RAW 264.7 macrophage cells. Int J Mol Sci 2020, 21, https://doi.org/10.3390/ijms21041355. 
36. Aziz, R.S.; Siddiqua, A.; Shahzad, M.; Shabbir, A.; Naseem, N. Oxyresveratrol ameliorates ethanol-induced gastric ulcer via downregulation of IL-6, TNF- $\alpha$, NF-kB, and COX-2 levels, and upregulation of TFF-2 levels. Biomed Pharmacother 2019, 110, 554-560, https://doi.org/10.1016/j.biopha.2018.12.002.

37. Bhattacharya, E.; Dutta, R.; Chakraborty, S.; Biswas, S.M. Phytochemical profiling of Artocarpus lakoocha Roxb. leaf methanol extract and its antioxidant, antimicrobial and antioxidative activities. Asian Pac J Trop Biomed 2019, 9, 484-492, https://doi.org/10.4103/2221-1691.270984.

38. Saleem, M.; Asiff, A.; Akhtar, M.F.; Saleem, A. Hepatoprotective potential and chemical characterization of Artocarpus lakoocha fruit extract. Bangladesh J Pharmacol 2018, 13, 90-97, https://doi.org/10.3329/bjp.v13i1.34117.

39. Nasution, R.; Fitrah, C.N.; Helwati, H.; Murniana; Arifin, B.; Cutchamzurni; Rizal, Y.; Marianne, M. Antidiabetes activities extract hexane from the peels of Artocarpus camansi blanco fruit. Asian J Pharm Clin Res 2018, 11, 12-17, https://doi.org/10.22159/ajpcr.2018.v11s1.26554.

40. Liu, X.; Kuang, X.D.; He, X.R.; Ren, G.; Wang, Y.; Xu, L.Y.; Feng, L.H.; Wang, B.; Zhou, Z.W. Prenylflavonoids from the twigs of Artocarpus nigrifolius. J-STAGE 2018, 66, 434-438, https://doi.org/10.1248/cpb.c17-00958.

41. Biharee, A.; Sharma, A.; Kumar, A.; Jaitak, V. Antimicrobial flavonoids as a potential substitute for overcoming antimicrobial resistance. Fitoterapia 2020, 146, https://doi.org/10.1016/j.fitote.2020.104720.

42. Palupi, D.H.; Retnoningrum, D.S.; Iwo, M.I.; Seomardji, A.A. Leaf extract of Artocarpus altilis [Park.] Fosberg has potency as anti-inflammatory, antioxidant, and immunosuppressant. Rasayan J Chem 2020, 13, 636-646, https://doi.org/10.31788/RJC.2020.1315519.

43. Ajiboye, B.O.; Ojo, O.A.; Adeyonu, O.; Imiere, O.; Olayide, I.; Fadaka, A.; Oyinloye, B.E. Inhibitory effect on key enzymes relevant to acute type-2 diabetes and antioxidative activity of ethanolic extract of Artocarpus heterophyllus stem bark. J Acute Dis 2016, 5, 423-429, https://doi.org/10.1016/j.joad.2016.08.011.

44. Akanni, O.O.; Owumi, S.E.; Adaramoye, O.A. In vitro studies to assess the antioxidative, radical scavenging and arginase inhibitory potentials of extracts from Artocarpus altilis, Ficus exasperate and Kigelia Africana. Asian Pac J Trop Biomed 2014, 4, 492-499, https://doi.org/10.12980/APJTB.4.2014C581.

45. Nagala, S.; Yekula, M.; Tamanam, R.R. Antioxidant and gas chromatographic analysis of five varieties of jackfruit (Artocarpus) seed oils. Drug Invent Today 2013, 5, 315-320, https://doi.org/10.1016/j.dit.2013.08.001.

46. Adan, A.A.; Ojwang, R.A.; Muge, E.K.; Mwanza, B.K.; Nyaboga, E.N. Phytochemical composition and essential mineral profile, antioxidant and antimicrobial potential of unutilized parts of jackfruit. Food Res 2020, 4, 1125-1134, https://doi.org/10.26656/fr.2017.4(4).326.

47. Jamil, M.M.; Haneson, S.; Mammam, H.B.; Wahab, R.A. Artocarpus altilis extract effect on cervical cancer cells. Mater Today 2018, 5, 15559-15566, https://doi.org/10.1016/j.matpr.2018.04.163.

48. Tantengco, O.A.; Jancito, S.D. Cytotoxic activity of crude extracts and fractions from Premna odorata (Blanco), Artocarpus camansi (Blanco) and Gliricidia sepium (Jacq.) against selected human cancer cell lines. Asian Pac J Trop Biomed 2015, 5, 1037-1041, https://doi.org/10.1016/j.apjtb.2015.09.011.

49. Saito, H.; Tamura, M.; Imai, K.; Ishigami, T.; Ochiai, K. Catechin inhibits Candida albicans dimorphism by disrupting Cek1 phosphorylation and cAMP synthesis. Microb Pathog 2013, 56, 16-20, https://doi.org/10.1016/j.micpath.2013.01.002.

50. Riasari, H.; Ulfah, M.; Prayugo, D.; Komariah, N.A. Antibacterial and antifungal activities of various bread fruit leaves (Artocarpus altilis (Parkinson) Fosberg). Int J Pharm Sci 2017, 8, 1066-1073, https://doi.org/10.13040/IJPSR.0975-8232.8(3).1066-73.

51. Hafid, A.F.; Utsubo, C.A.; Permanasari, A.A.; Adianti, M.; Tumewu, L.; Widyawaruyanti, A.; Wahyuningsih, S.P.; Wahyuni, T.S.; Lusida, M.I.; Soetjipto; Hotta, H. Antiviral activity of the dichloromethane extracts from Artocarpus heterophyllus leaves against hepatitis C virus. Asian Pac J Trop Biomed 2017, 7, 633-639, https://doi.org/10.1016/j.apjtb.2017.06.003.

52. Lalani, S.; Poh, C.L. Flavonoids as antiviral agents for Enterovirus A71 (EV-A71). Viruses 2020, 12, https://doi.org/10.3390/v12020184.

53. Hidayati, A.R.; Widyawaruyanti, A.; Ilmi, H.; Tanjung, M.; Widiandani, T.; Siswandono; Syafruddin, D.; Hafid, A.F. Antimalarial activity of flavonoid compound isolated from leaves of Artocarpus altilis. Pharmacogn J 2020, 12, 835-842, https://doi.org/10.5530/pj.2020.12.120. 